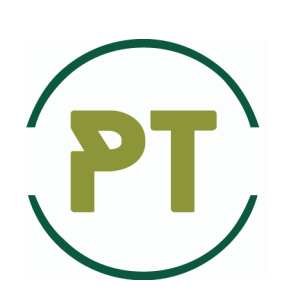

Problems of Tribology, V. 25, No 3/97-2020, 55-63

Problems of Tribology

Website: http://tribology.khnu.km.ua/index.php/ProbTrib

E-mail: tribosenator@gmail.com

DOI: https://doi.org/10.31891/2079-1372-2020-97-3-55-63

\title{
Plane contact problem on the interaction of a pre-stressed strip with an infinite inhomogeneous stringer
}

\author{
N.N. Dikhtyaruk, E.A. Poplavskaya* \\ Khmelnytsky National University, Ukraine \\ E-mail: helen.poplavskaya@gmail.com
}

\begin{abstract}
The article is devoted to the study of problems of contact interaction of an infinite elastic inhomogeneous stringer with a prestressed strip clamped along one edge. As a result of the research, we have obtained a resolving system of recurrent systems of integro-differential equations. In general, the studies were carried out for the theory of large initial and various versions of the theory of small initial deformations within the framework of the linearized theory of elasticity with an elastic potential of an arbitrary structure. Integral integer differential equations are obtained using the integral Fourier transform. Their solution is presented in the form of quasiregular infinite systems of algebraic equations. The article also investigates the influence of the initial (residual) stresses in strips on the distribution law of contact stresses along the line of contact with an infinite stringer. The system is solved in a closed form using the Fourier transform. The stress expressions are represented by Fourier integrals with a fairly simple structure. The influence of the initial stress on the distribution of contact stresses has been studied and mechanical effects have been found under the action of concentrated loads.
\end{abstract}

Keywords: linearezed theory of elasticity, initial (residual) stresses, initial deformations, prestressed elastic strip, transformation of Fourier.

\section{Introduction}

The linearized theory of elasticity is used to solve the plane contact problem of transferring a horizontal and vertical concentrated load from an infinite inhomogeneous stringer to a prestressed strip clamped at one edge. As a result of the research, we have obtained a resolving system of recurrent systems of integro-differential equations. Consequently, the solution of the contact problem for a prestressed strip reinforced by an inhomogeneous infinite stringer reduces to solving a number of homogeneous contact problems differing only in similar external loads. A general solution is found for the theory of large initial deformations and various theories of small initial deformations for an arbitrary elastic potential. The problem for normal and tangential contact stresses is reduced to a system of integro-differential equations derived using the Fourier transform. Contact voltages are represented by Fourier integrals. It is shown that the initial stresses in the strips strongly affect the distribution of contact stresses: contact stresses significantly decrease in compression and increase in tension, while displacements increase in compression and decrease in tension. The influence of initial stresses is stronger in highly elastic materials than in rigid ones.

\section{Isolation of previously unresolved parts of a common problem}

Despite the fact that studies of the effect of initial stresses began to be actively carried out in our country and abroad only at the end of the 20th century, it is possible to list many names, studies and publications related to this topic $[1,2]$. Despite a significant achievement in the development of contact problems, the issue of taking into account the initial stresses during contact interaction has remained almost completely undeveloped until recently.

In all real structures and machine parts, there are almost always initial or residual stresses. The reasons for their occurrence can be different. Often, initial stresses in parts and structures are created specifically during 
their manufacture or assembly. They can also appear during operation both under the influence of mechanical factors, such as irreversible plastic deformation, and for reasons that are non-mechanical in nature (chemical processes)

At present, various coatings are widely used in technology to improve the strength properties of parts, the possibility of their use at elevated temperatures or in the presence of aggressive media. Since such parts are often critical structural elements, whose destruction can lead to catastrophic consequences, they need to be regularly diagnosed and reinforced. With a strict formulation of contact problems for elastic bodies with initial stresses [1, 2], it becomes necessary to use the apparatus of the nonlinear theory of elasticity, which significantly complicates the construction of analytical solutions. But in the case of large (finite) stresses (deformations), one can restrict oneself to considering the linearized theory of elasticity [1].

Historically, the study of contact problems within the framework of the linearized theory of elasticity developed in two directions. The first is associated with the study of contact interaction of bodies with a specific form of elastic potential [3]. In the second, the problem is posed in general form for compressible (incompressible) bodies with a potential of an arbitrary structure on the basis of the linearized theory of elasticity $[1,2,4-13]$.

In this paper, using the relations of the linearized theory of elasticity [1,2], solutions of contact problems on the contact interaction of an infinite inhomogeneous stringer with a prestressed strip are presented. The study was carried out in general form for compressible and incompressible bodies for the theory of large (finite) initial deformations and two versions of the theory of small initial deformations for an arbitrary structure of the elastic potential.

\section{The purpose of the work}

The purpose of the work is to study of the influence of initial (residual) stresses on the distribution and displacement law under the stringer, along the line of contact. Further consideration of the class of contact problems on the contact interaction of elastic stringers with a prestressed strip. To study the influence of the initial (residual) stresses on the distribution law of contact stresses during the reinforcement of elements along the line of direct contact as a result of the action of a concentrated force on an elastic inhomogeneous stringer. In the case of the presence of some elastic potentials of the simplest design, perform numerical calculations and graphing.

\section{Presentation of the main material}

1. Problem statement and initial resolving equations. Let an elastic homogeneous strip with initial stresses of thickness $t$ be clamped by the face $y_{2}=-t$ and on its other facet $y_{2}=0$ it is reinforced by an inhomogeneous infinite elastic stringer of small thickness $h$. This infinite elastic strip with initial stresses is subjected to the action of vertical and horizontal forces of intensities $p_{0}\left(y_{1}\right)$ and $q_{0}\left(y_{1}\right)$, accordingly in the Figure 1.

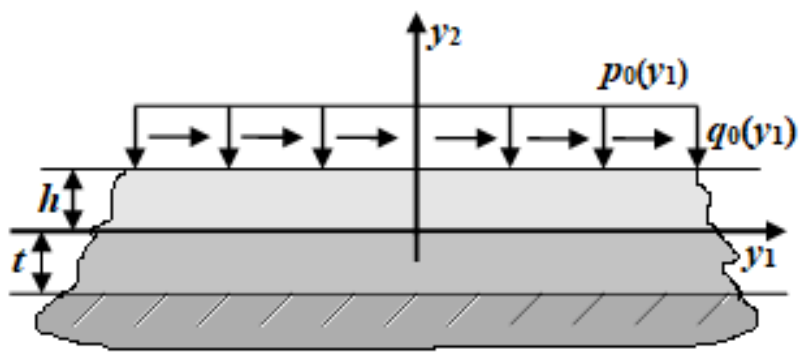

Fig. 1.

The carried out research is adhering to the framework of the linearized theory of elasticity with an arbitrary structure of the elastic potential, in general form for the theory of large (finite) and several versions of the theory of small initial deformations. In passing to various versions of the theory of small initial deformations, the introduced are simplifications indicated in [1]. Following [1], to solve the problem posed, solutions are used for compressible and incompressible bodies in the coordinates of the deformed initial state $y_{i}=\lambda_{i} x_{i}, \quad(i=1,2)$, where $\lambda_{i}$ - the elongation coefficients that determine the displacements of the initial state in the directions of the coordinate axes. Then the displacements that determine the initial state in the case of uniform initial stresses have the form:

$$
u_{m}^{0}=\delta_{i m} \cdot\left(\lambda_{i}-1\right) \cdot x_{i}=\delta_{i m} \cdot\left(\lambda_{i}-1\right) \cdot \lambda_{i}^{-1} y_{i}
$$


Where $\lambda_{i}(i=1,2)$ - the elongations that characterize the initial deformed state; $x_{i}$ - lagrangian coordinates; $u_{m}^{0}$ - displacements that define the initial state; $\delta_{i m}$ - components of the metric strain tensor. The plane strain case considered when $s_{0}^{11} \neq 0, s_{0}^{22}=0, \lambda_{1} \neq \lambda_{2}=\lambda_{3}, \lambda_{3}=1$, where $s_{0}^{11}, s_{0}^{22}, \lambda_{3}$ - known quantities that depend on the initial stress state and the type of elastic potential.

According to Hooke's law, we find the axial stress in the direction of the axis $O y_{1}$ :

$$
\begin{gathered}
\sigma_{y_{1} y_{1}}\left(y_{1}\right)=E_{1} \varepsilon_{y_{1} y_{1}}\left(y_{1}\right) ; \\
\varepsilon_{y_{1} y_{1}}\left(y_{1}\right)=\frac{d u\left(y_{1}\right)}{d y_{1}},
\end{gathered}
$$

where $u\left(y_{1}\right)$ - horizontal displacements of the points of the elastic stringer.

Using the equilibrium conditions of the elastic stringer, we have:

$$
\sigma_{y_{1} y_{1}}\left(y_{1}\right)=\frac{1}{h} \int_{-\infty}^{y_{1}}\left[q(t)-q_{0}(t)\right] d t, \quad\left(-\infty<y_{1}<\infty\right)
$$

Taking into account (1.1) - (1.4), we find:

$$
\frac{d u\left(y_{1}\right)}{d y_{1}}=\frac{1}{E_{1} h} \int_{-\infty}^{y_{1}}\left[q(t)-q_{0}(t)\right] d t,\left(-\infty<y_{1}<\infty\right)
$$

From the assumption that the stringer bends in the vertical direction like an ordinary beam, we can write:

$$
D \frac{d^{4} v\left(y_{1}\right)}{d y_{1}^{4}}=p\left(y_{1}\right)-p_{0}\left(y_{1}\right),\left(-\infty<y_{1}<\infty\right),
$$

where $v\left(y_{1}\right)$ - vertical movement of stringer points;

$D$ - the stringer bending stiffness;

$p_{0}\left(y_{1}\right), p\left(y_{1}\right)$ - intensity of vertical forces.

On the line of contact of the stringer with the elastic strip, the following conditions take place:

$$
u\left(y_{1}\right)=u_{1}\left(y_{1}\right), \quad v\left(y_{1}\right)=u_{2}\left(y_{1}\right), \quad \forall y_{1} \in\left(-\infty<y_{1}<\infty\right)
$$

where $u_{1}\left(y_{1}\right), u_{2}\left(y_{1}\right)$ - displacement of points in an elastic strip with initial stresses. It is necessary to determine the distribution law of normal and tangential contact stresses along the line of connection of the stringer with the strip.

To determine the unknown displacements and stresses along the line of contact of the stringer with the strip, we first solve the auxiliary problem. Let us find the field of elastic displacements and stresses in a prestressed infinite strip from the action of a concentrated force applied $P$ to its free face directed at an arbitrary angle $\alpha_{0}$, using the integral Fourier transform.

Let us write down the boundary conditions of the problem for the upper face of the elastic strip with initial stresses from the applied force at an angle.

$$
\begin{gathered}
\widetilde{Q}_{11}\left(y_{1}, 0\right)=-P \delta\left(y_{1}\right) \cdot \cos \alpha_{0} ; \\
\widetilde{Q}_{22}\left(y_{1}, 0\right)=-P \delta\left(y_{1}\right) \cdot \sin \alpha_{0} . \\
u_{1}\left(y_{1}-t\right)=0 ; u_{2}\left(y_{1}-t\right)=0 ;\left(-\infty<y_{1}<\infty\right),
\end{gathered}
$$

where $\delta\left(y_{1}\right)-$ Dirac delta function.

As result of solving the problem posed, the influence functions from the action of the normal force at $\alpha_{0}=\frac{\pi}{2}$ for equal roots $\left(n_{1}=n_{2}\right)$ have the form:

- for equal roots $\left(n_{1}=n_{2}\right)$ : 


$$
\begin{aligned}
& h_{11}\left(y_{1}\right)=\frac{1}{\pi} \int_{0}^{\infty} H_{11}(\alpha) \cdot \cos \alpha \cdot y_{1} d \alpha, \\
& h_{12}\left(y_{1}\right)=\frac{1}{\pi} \int_{0}^{\infty} H_{12}(\alpha) \cdot \sin \alpha \cdot y_{1} d \alpha ;
\end{aligned}
$$

- for unequal roots $\left(n_{1} \neq n_{2}\right)$ :

$$
\begin{aligned}
& h_{11}\left(y_{1}\right)=\frac{1}{\pi} \int_{0}^{\infty} \tilde{H}_{11}(\alpha) \cdot \cos \alpha \cdot y_{1} d \alpha, \\
& h_{12}\left(y_{1}\right)=\frac{1}{\pi} \int_{0}^{\infty} \tilde{H}_{12}(\alpha) \cdot \sin \alpha \cdot y_{1} d \alpha,
\end{aligned}
$$

where $h_{i j}(\alpha), \quad(i, j=1,2)$ - influence functions that characterize the displacements of the boundary points of the facet $y_{2}=0$ of an infinite elastic strip with initial stresses from a unit normal force. The nuclei $H_{i j}(\alpha), \widetilde{H}_{i j}(\alpha)$ are of the form [3]:

- for equal roots $\left(n_{1}=n_{2}\right)$ :

$$
\begin{aligned}
& H_{11}(\alpha)=H_{1}(\alpha, 0)=n_{0}\left[s_{0} s h^{2} \alpha \varphi_{1}+s_{1} s_{0} s h^{2} \alpha \varphi_{1}-\right. \\
& \left.-\alpha \varphi_{1} \xi(\alpha)+\left(\alpha \varphi_{1}\right)^{2}-\bar{s}_{1} \xi(\alpha)+\varphi_{1}\right] \Delta_{1}^{-1}(\alpha), \\
& H_{12}(\alpha)=H_{2}(\alpha, 0)=i \frac{m_{1} n_{0}}{\sqrt{n_{1}}}\left[s_{0} s \xi(\alpha)-s_{0}\left(\alpha \varphi_{1}\right)-\right. \\
& \left.-\bar{s}_{1} s_{1} \xi(\alpha)+s_{1}\left(\alpha \varphi_{1}\right)\right] \Delta_{1}^{-1}(\alpha)
\end{aligned}
$$

- for unequal roots $\left(n_{1} \neq n_{2}\right)$ :

$$
\begin{aligned}
& \widetilde{H}_{11}(\alpha)=\widetilde{H}_{1}(\alpha, 0)=n_{0}\left[-s_{1} \operatorname{ch}\left(2 \alpha \varphi_{1}\right)+s_{0} \xi_{1}(\alpha)-s_{1} s_{0}\left(\alpha \varphi_{1}\right) \xi_{1}(\alpha)+\right. \\
& \left.+s_{0}\left(\alpha \varphi_{1}\right)^{2} \operatorname{sh}^{2}\left(\alpha \varphi_{1}\right)-s_{0} c h^{2}\left(\alpha \varphi_{1}\right)+s_{1} \xi_{1}(\alpha)+\alpha \varphi_{1} \xi_{4}(\alpha)\right] \times \Delta_{2}^{-1}(\alpha), \\
& \widetilde{H}_{12}(\alpha)=\widetilde{H}_{2}(\alpha, 0)=i \frac{n_{0} m_{1}}{\sqrt{n_{1}}}\left[s_{0} s_{1} \xi_{3}(\alpha)-s_{0}\left(\alpha \varphi_{1}\right) \xi_{1}(\alpha)+\right. \\
& \left.+s_{1}\left(\alpha \varphi_{1}\right) \xi(\alpha)-s_{1} \xi_{1}(\alpha)\right] \times \Delta_{2}^{-1}(\alpha) .
\end{aligned}
$$

The functions of influence from the action of a unit tangential force (at the $\alpha_{0}=0$ ) for equal roots $\left(n_{1}=n_{2}\right)$ are as follows:

$$
\begin{aligned}
& h_{21}\left(y_{1}\right)=\frac{1}{\pi} \int_{0}^{\infty} H_{21}(\alpha) \cdot \sin \alpha \cdot y_{1} d \alpha, \\
& h_{22}\left(y_{1}\right)=\frac{1}{\pi} \int_{0}^{\infty} H_{22}(\alpha) \cdot \cos \alpha \cdot y_{1} d \alpha .
\end{aligned}
$$

For the unequal roots $\left(n_{1} \neq n_{2}\right)$ we can write:

$$
\begin{aligned}
& h_{21}\left(y_{1}\right)=\frac{1}{\pi} \int_{0}^{\infty} \widetilde{H}_{21}(\alpha) \cdot \sin \alpha \cdot y_{1} d \alpha, \\
& h_{22}\left(y_{1}\right)=\frac{1}{\pi} \int_{0}^{\infty} \widetilde{H}_{22}(\alpha) \cdot \cos \alpha \cdot y_{1} d \alpha .
\end{aligned}
$$

The nuclei $H_{i j}(\alpha)$ and $\widetilde{H}_{i j}(\alpha)$, accordingly, have the form [3]: 
- for $n_{1}=n_{2}$ :

$$
\begin{aligned}
& H_{21}(\alpha)=m_{0}\left[-(s+1)\left(s_{1} \xi(\alpha)-\alpha \varphi_{1}\right)+\operatorname{ch}^{2} \alpha \varphi_{1}-s_{1} \operatorname{sh}^{2} \alpha \varphi_{1}-s\right]= \\
& =m_{0}\left[-(s+1)\left(s_{1} \operatorname{sh} \alpha \varphi_{1} \operatorname{ch} \alpha \varphi_{1}-\alpha \varphi_{1}\right)+\operatorname{ch}^{2} \alpha \varphi_{1}-s_{1} \operatorname{sh}^{2} \alpha \varphi_{1}-s\right] \cdot \Delta_{1}^{-1}(\alpha), \\
& H_{22}(\alpha)=i \frac{m_{0} m_{1}}{\sqrt{n_{1}}}\left[s \cdot s_{1} \operatorname{ch}^{2} \alpha \varphi_{1}+\left(\alpha \varphi_{1}\right)^{2}-\alpha \varphi_{1} \xi(\alpha)-s_{1}^{2} \operatorname{sh}^{2}\left(\alpha \varphi_{1}\right)-\right. \\
& \left.-s \cdot s_{1}\right] \cdot \Delta_{1}^{-1}(\alpha)
\end{aligned}
$$

- for $n_{1} \neq n_{2}$ :

$$
\begin{aligned}
& \widetilde{H}_{21}(\alpha)=m_{0}\left[-s s_{1}\left(\alpha \varphi_{1}\right) \xi_{2}(\alpha)-s \xi_{3}(\alpha)+s\left(\alpha \varphi_{1}\right) \xi_{2}(\alpha)+\xi_{3}(\alpha)\right] \cdot \Delta_{2}^{-1}(\alpha), \\
& \widetilde{H}_{22}(\alpha)=i \frac{m_{0} m_{1}}{\sqrt{n_{1}}}\left[1-s_{1} \operatorname{ch}\left(2 \alpha \varphi_{2}\right)+s s_{1} \xi_{1}(\alpha)+s \alpha \varphi_{1} \xi_{4}(\alpha)+\right. \\
& \left.+s s_{1}\left(\alpha \varphi_{1}\right)^{2} s h^{2} \alpha \varphi_{1}-s s_{1} c h^{2} \alpha \varphi_{21}-s_{1}^{2}\left(\alpha \varphi_{1}\right) \xi_{4}(\alpha)+\xi_{3}(\alpha)\right] \cdot \Delta_{2}^{-1}(\alpha) .
\end{aligned}
$$

Here are the roots of the governing equation [1]. The quantities appearing in formulas (1.12), (1.13), (1.15), (1.16), (1.17) are expressed through the known parameters of the initial stress state [3, 4].

2. Resolving system of recurrent systems of equations. Using the principle of superposition, the displacements of points of an elastic strip with initial stresses in the direction of the axes $0 y_{1}$ and $0 y_{2}$ from the simultaneous action of normal and tangential stresses for compressible and incompressible bodies in the case of elastic potentials of an arbitrary structure are determined by the formulas [3]:

$$
\begin{aligned}
& u_{1}\left(y_{1}\right)=\int_{-\infty}^{\infty} h_{11}\left(\left|y_{1}-\tau\right|\right) p(\tau) d \tau+\int_{-\infty}^{\infty} h_{12}\left(\left|y_{1}-\tau\right|\right) q(\tau) d \tau, \\
& u_{2}\left(y_{1}\right)=\int_{-\infty}^{\infty} h_{21}\left(\left|y_{1}-\tau\right|\right) p(\tau) d \tau+\int_{-\infty}^{\infty} h_{22}\left(\left|y_{1}-\tau\right|\right) q(\tau) d \tau .
\end{aligned}
$$

Following [3, 4], according to the accepted assumptions and notation, the problem can be formulated as a system of equations:

$$
\begin{aligned}
& \frac{d^{2}}{d y_{1}^{2}}\left[D\left(y_{1}\right) \frac{d^{2} u_{2}\left(y_{1}\right)}{d y_{1}^{2}}\right]=p\left(y_{1}\right)-p_{0}\left(y_{1}\right), \\
& E_{1}\left(y_{1}\right) h \frac{d u_{1}\left(y_{1}\right)}{d y_{1}}=\int_{-\infty}^{y_{1}}\left[q(\tau)-q_{0}(\tau)\right] d \tau, \\
& -\infty<y_{1}<\infty,
\end{aligned}
$$

where $D\left(y_{1}\right)=I E_{1}\left(y_{1}\right)$ - the stringer bending stiffness;

$I-$ the inhomogeneity parameter.

Let the stringer material have a weak inhomogeneity varying according to the law:

$$
E_{1}\left(y_{1}\right)=E\left[\left(1+\delta f\left(y_{1}\right)\right], \quad\left(-\infty<y_{1}<\infty\right),\right.
$$

where $f\left(y_{1}\right)$ - some famous function;

$\delta$ - small parameter.

Using the contact conditions (1.6) and representing the unknown contact stresses $p_{0}\left(y_{1}\right), q_{0}\left(y_{1}\right)$ as a series in powers of a small parameter, we can write:

$$
\begin{aligned}
& p_{0}\left(y_{1}\right)=\sum_{k=0}^{\infty} \delta^{k} p^{(k)}\left(y_{1}\right),-\infty<y_{1}<\infty . \\
& q_{0}\left(y_{1}\right)=\sum_{k=0}^{\infty} \delta^{k} q^{(k)}\left(y_{1}\right) .
\end{aligned}
$$


From (2.2) with the help of (2.3), (2.4), as well as formulas (2.1), we obtain a resolving system of recurrent systems of integro-differential equations:

$$
\begin{gathered}
D_{0} \frac{d^{4} u_{2}{ }^{(0)}\left(y_{1}\right)}{d\left(y_{1}\right)^{4}}=p^{(0)}\left(y_{1}\right)-p_{0}\left(y_{1}\right), \\
E_{0} h \frac{d^{2} u_{1}{ }^{(0)}\left(y_{1}\right)}{d\left(y_{1}\right)^{2}}=q^{(0)}\left(y_{1}\right)-q_{0}\left(y_{1}\right), \\
-\infty<y_{1}<\infty . \\
D_{0} \frac{d^{4} u_{2}^{(k)}\left(y_{1}\right)}{d\left(y_{1}\right)^{4}}=p^{(k)}\left(y_{1}\right)-f_{1}^{(k-1)}\left(y_{1}\right), \\
E_{0} h \frac{d^{2} u_{1}^{(k)}\left(y_{1}\right)}{d\left(y_{1}\right)^{2}}=q^{(k)}\left(y_{1}\right)-f_{2}^{(k-1)}\left(y_{1}\right), \\
k=1,2, \ldots . .
\end{gathered}
$$

Where

$$
\begin{aligned}
& u_{1}\left(y_{1}\right)=\int_{-\infty}^{\infty} h_{21}\left(y_{1}-\tau\right) p^{(k)}(\tau) d \tau+\int_{-\infty}^{\infty} h_{22}\left(\left|y_{1}-\tau\right|\right) q^{(k)}(\tau) d \tau, \\
& u_{2}\left(y_{1}\right)=\int_{-\infty}^{\infty} h_{11}\left(\left|y_{1}-\tau\right|\right) p^{(k)}(\tau) d \tau+\int_{-\infty}^{\infty} h_{12}\left(y_{1}-\tau\right) q^{(k)}(\tau) d \tau, \\
& -\infty<y_{1}<\infty, \quad k=0,1, \ldots, \\
& f_{1}^{(k-1)}\left(y_{1}\right)=D_{0} \frac{d^{2}}{d\left(y_{1}\right)^{2}}\left[f\left(y_{1}\right) \frac{d^{2} u_{2}^{(k-1)}\left(y_{1}\right)}{d\left(y_{1}\right)}\right], k=1,2, \ldots, \\
& f_{2}^{(k-1)}\left(y_{1}\right)=E_{0} h \frac{d}{d\left(y_{1}\right)}\left[f\left(y_{1}\right) \frac{d u_{1}^{(k-1)}\left(y_{1}\right)}{d\left(y_{1}\right)}\right], \\
& D_{0}=E_{0} I .
\end{aligned}
$$

Here $D_{0}-$ the zero term of the series expansion.

System (2.5) describes a contact problem for a homogeneous infinite stringer [3], each subsequent system from (2.6) differs from the previous one only by the external load. Consequently, the solution of a contact problem for a prestressed strip reinforced by an inhomogeneous infinite stringer reduced to solving a number of homogeneous contact problems that differ only in similar external loads. The zero approximation of the solution, that is, the solution of system (2.5) using the Fourier transform, was constructed in [3] and takes the form:

$$
\begin{aligned}
& \begin{array}{l}
p\left(y_{1}\right)=\frac{\mu}{2 \pi} \int_{-\infty}^{\infty}\left[\alpha^{2} H_{21}^{*}(\alpha) \widetilde{q}_{0}(\alpha)+H_{22}^{*}(\alpha) \widetilde{p}_{0}(\alpha)\right] \cdot H^{-1}(\alpha) e^{-i \alpha y_{1}} d \alpha \\
\quad-\infty<y_{1}<\infty
\end{array} \\
& q\left(y_{1}\right)=\frac{\mu}{2 \pi} \int_{-\infty}^{\infty}\left[H_{11}^{*}(\alpha) \widetilde{q}_{0}(\alpha)-i H_{12}^{*}(\alpha) \widetilde{p}_{0}(\alpha)\right] \cdot H^{-1}(\alpha) e^{-i \alpha y_{1}} d \alpha .
\end{aligned}
$$

Here the quantities $H^{-1}(\alpha), H_{i j}^{*}(\alpha),(i, j=1,2)$ expressed in terms of known functions $H_{i j}(\alpha)$ and $\widetilde{H}_{i j}(\alpha), \quad(i, j=1,2)$, which are determined according to the formulas for equal and unequal roots of the constitutive equation $[1,3,5]$ in the case of a specific structure of elastic potentials. The rest of the approximations of solutions, which are influenced by the inhomogeneity of the stringer material, are constructed in a similar way; $\widetilde{p}_{0}(\alpha)$ and $\widetilde{q}_{0}(\alpha)$ - Fourier transforms of functions of contact voltages along the contact line, $\mu$ - Lamé coefficient.

Thus, the $k$-th approximation has the form: 


$$
\begin{aligned}
& p^{(k)}\left(y_{1}\right)=\frac{1}{2 \pi} \int_{-\infty}^{\infty} P^{(k)}(s) e^{-i s y_{1}} d s, k=1,2, \ldots . \\
& q^{(k)}\left(y_{1}\right)=\frac{1}{2 \pi} \int_{-\infty}^{\infty} Q^{(k)}(s) e^{-i s y_{1}} d s,
\end{aligned}
$$

Where

$$
\begin{aligned}
P^{(k)}(s) & =\frac{D s^{2}\left\{\bar{f}_{1}^{(k-1)}(s)\left[E_{0} h s^{2} H_{22}(s)+1\right]-E_{0} h s^{3} \bar{f}_{2}^{(k-1)}(s) H_{12}(s)\right\}}{L(s)}, \\
k=1,2, \ldots, & \\
Q^{(k)}(s) & =\frac{\left.-I E_{0}\left\{h s \bar{f}_{2}^{(k-1)}(s) D_{0} h s^{4} H_{11}(s)+1\right]+D_{0} h s^{3} \bar{f}_{1}^{(k-1)}(s) H_{12}(s)\right\}}{L(s)},
\end{aligned}
$$

are the Fourier transforms of contact stresses. In the (2.9):

$$
\begin{aligned}
& L(s)=\left[D_{0} s^{4} H_{11}(s)-1\right]\left[E_{0} h s^{2} H_{22}(s)+1\right]+D_{0} E_{0} s^{4} h H_{12}^{2}(s), \\
& \bar{f}_{j}^{(k-1)}(s)=F\left[f_{j}^{(k-1)}\left(y_{1}\right)\right], j=1,2, \quad k=1,2, \ldots
\end{aligned}
$$

Here $\mathrm{F}$ - the Fourier transform operator for the indicated function (functional).

3. Solving systems of resolving equations. Applying to both parts of system (2.8) the integral Fourier transform with respect to the variable $y_{1}$ and using the convolution theorem, we find expressions for the contact stresses in elastic strips with initial stresses. The zero approximation of the solution for the case of equal and unequal roots of the resolving equation takes the form (2.8) if in these formulas the replacement is made:

- for equal roots $\left(n_{1}=n_{2}\right) H_{i j}^{*}(\alpha)$ on the $H_{i j}(\alpha)$;

- for unequal roots $\left(n_{1} \neq n_{2}\right) H_{i j}^{*}(\alpha)$ on the $\widetilde{H}_{i j}(\alpha)$.

Where the nuclei $H_{i j}(\alpha)$ and $\widetilde{H}_{i j}(\alpha)$, respectively, have the form (1.17).

Consider numerical examples for incompressible bodies of neoguk material (Treloar potential) (Fig. 2, 3).

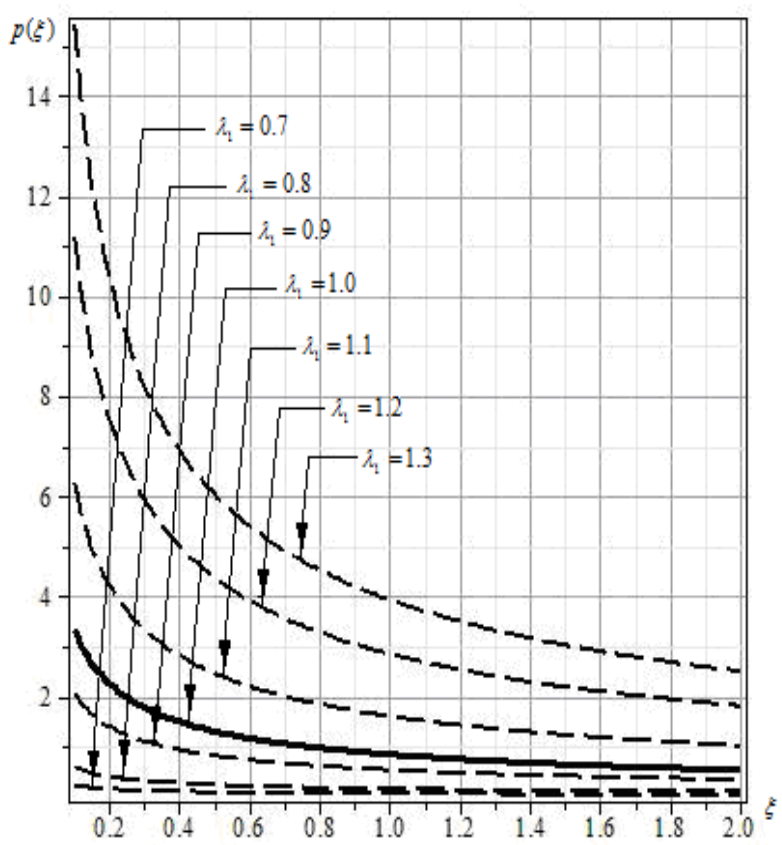

Fig. 2. Intensity of normal contact stresses under the stringer 


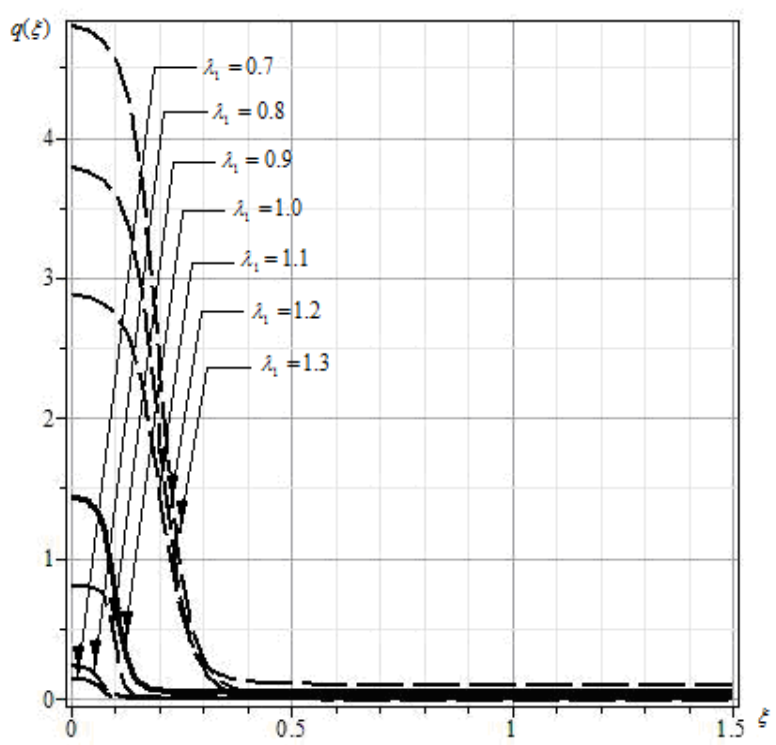

Fig. 3. Intensity of tangential contact stresses under the stringer

Here $p(\xi), q(\xi))$ - dimensionless contact normal and tangential stresses. Value $\lambda_{1}=1$ (solid line on the graphs) corresponds to the classical theory of elasticity and coincides with the result of work $[8] ; \lambda_{1}=0,7 ; 0,8 ; 0,9$ - corresponds to the initial compression stresses; $\lambda_{1}=1,1 ; 1,2 ; 1,3$ - corresponds to the initial tensile stresses; $\xi$-dimensionless coordinate of the initial stress state in an elastic strip with initial stresses.

Analysis of the graphs shows: in a case of compression $\left(\lambda_{1}<1\right)$ the presence of initial stresses in the elastic strip leads to a significant decrease in contact stresses, in the case of tension $\left(\lambda_{1}>1\right)-$ to their increase.

\section{Conclusions}

In this work, within the framework of the linearized theory of elasticity, a solution to the plane problem of transferring a horizontal concentrated load from a weakly inhomogeneous infinite stringer to an elastic infinite strip clamped by one face with initial stresses obtained. The investigations were carried out in general form for the theory of large initial deformations and several versions of the theory of small initial deformations for an arbitrary structure of the elastic potential. The solution of the problem are reduced with respect to normal and tangential contact stresses to a resolving system of recurrent systems of integro-differential equations, the solution for which is constructed in powers of a small parameter. The zero approximation of the solution to the inhomogeneous problem are construction using the integral Fourier transform. Ultimately, a contact stresses are represented as Fourier integrals.

\section{References}

1. Гузь А.Н., Бабич С.Ю., Глухов Ю.П. Смешанные задачи для упругого основания с начальными напряжениями. - Saarbrücken: LAP LAMBERT Academic Publishing, 2015. - 468 c.

2. Гузь О.М., Бабич С.Ю., Рудницький В.Б. Контактна взаємодія пружних тіл $з$ початковими напруженнями. - Київ.: Вища шк., 1995. - 305 с.

3. Діхтярук М.М. Визначення функції впливу для пружної смуги з початковими (залишковими) напруженнями // Пр. 4-го Міжнародного симпозіуму з трибофатики (ISTF), 23 - 27 вересня 2002 р. Тернопіль (Україна) / Відп. ред. В.Т.Трощенко. - Тернопіль: Терноп. держ. техн. ун-т ім. Івана Пулюя, 2002. - C. $426-431$.

4. Діхтярук М.М. Періодична контактна задача для пружної смуги з початковими (залишковими) напруженнями // Доп. НАН України. - 2004. - № 3. - С. 46 - 49.

5. Саркисян В.С. Контактные задачи для полуплоскостей и полос с упругими накладками. Ереван: Изд. Ереван. ун-та, 1983. - 260 с.

6. Babich S.Yu. , Dikhtyaruk N.N., Degtyar S.V. Contact Problems for Prestressed Elastic Bodies and Rigid and Elastic Punches // Int. Appl. Mech. - 2019. - 55, N 6. - P. 629 - 635.

7. Dikhtyaruk N.N. Load transfer from the infinite stringer to the two jammed along one edge identical stripes with initial (residual) stresses // Scientific journal of the Ternopil national technical university. - 2016 83, №3. - P. $51-61$. 
8. Dikhtyaruk N.N., Kurinenko O.V., Poplavskaya E.A., Samaruk N.N. Interaction Between a Finite Stringer and Two Identical Prestressed Strips: Contact Problem // Int. Appl. Mech. - 2019. - 55, № 1. - P. 79 -85 .

9. Dikhtyaruk N.N . Equilibrium of a Prestressed Strip Reinforced with Elastic Plates // Int. Appl. Mech. - 2004. - 40, N 3. - P. $290-296$.

10. Rudnitsky V.B., Dikhtyaruk N.N. A Prestressed Elastic Strip with Elastic Reinforcements // Int. Appl. Mech. - 2002. - 38, № 11. - P. $1354-1360$.

11. Rudnitsky V.B., Dikhtyaruk N.N. Interaction Between an Infinite Stringer and Two Identical Prestressed Strips: Contact Problem // Int. Appl. Mech. - 2017. - 53, № 2. - P. 149 - 155.

12. Діхтярук М.М., Поплавська О.А. Аналог задачі Мелана для пружної смуги з початковими напруженнями підсиленною пружною накладкою / М. М. Діхтярук, О. А. Поплавська // Проблеми трибології. - 2018. - № 1. - С. 37 - 42.

13. Dikhtyaruk, N. N., Poplavskaya E. A. A flat contact problem the interaction two prestressed stripes with an infinite stringer / N. N. Dikhtyaruk, E. A. Poplavskaya // Problems of tribology. - 2019. - Vol. 24, No. 94/4. - P. 40-48.

14. Dikhtyaruk N. N. Contact problem of elastic strips with initial stresses with periodically placed resilient protective strap / N. N. Dikhtyaruk, O. V. Kurinienko, E. A. Poplavskaya // Problems of tribology. 2019. - Vol. 92, no. 2. - C. $6-12$.

Діхтярук М.М., Поплавська О.А.Плоска контактна задача про взаємодію попередньо напруженої смуги з нескінченним неоднорідним стрингером.

Стаття присвячена дослідженню задач контактної взаємодії нескінченного пружного неоднорідного стрингера із затиснутою з одного краю попередньо напруженою смугою. За результатами досліджень отримали розв'язну систему рекурентних систем інтегро-диференціальних рівнянь. У цілому дослідження проводилися для теорії великих початкових і різних варіантів теорії малих початкових деформацій у рамках лінеаризованої теорії пружності із пружним потенціалом довільної структури. Інтегральні цілочисельні диференціальні рівняння отримані за допомогою інтегрального перетворення Фур'є. Їх розв’язок представлено у вигляді квазірегулярних нескінченних систем алгебраїчних рівнянь. У статті також досліджено вплив початкових (залишкових) напружень у смузі на закон розподілу контактних напружень по лінії контакту 3 нескінченним стрингером. Система розв'язується у замкнутому вигляді з використанням перетворень Фур'є. Вирази напружень представлені інтегралами Фур'є 3 досить простою структурою. Вивчено вплив початкових напружень на розподіл контактних напружень і виявлені механічні ефекти при впливі зосереджених навантажень.

Ключові слова: лінеаризована теорія пружності, початкові (залишкові) напруження, початкові деформації, попередньо напружена пружна смуга, перетворення Фур'є. 